\title{
Utilization of Crushed Pavement Blocks in Concrete: Assessment of Functional Properties and Environmental Impacts
}

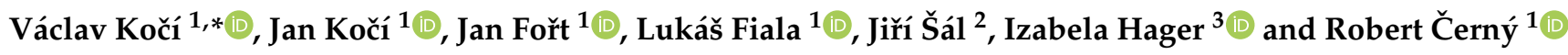 \\ 1 Department of Materials Engineering and Chemistry, Faculty of Civil Engineering, Czech Technical \\ University in Prague, Thákurova 7/2077, 16629 Prague 6, Czech Republic; jan.koci@fsv.cvut.cz (J.K.); \\ jan.fort@fsv.cvut.cz (J.F.); fialal@fsv.cvut.cz (L.F.); cernyr@fsv.cvut.cz (R.Č.) \\ 2 Institute of Technology and Business in České Budějovice, Okružní 517/10, 37001 České Budějovice, \\ Czech Republic; sal@mail.vstecb.cz \\ 3 Faculty of Civil Engineering, Cracow University of Technology, 24 Warszawska St., 31-155 Cracow, Poland; \\ ihager@pk.edu.pl \\ * Correspondence: vaclav.koci@fsv.cvut.cz; Tel.: +420-2-2435-7125
}

check for

updates

Citation: Kočí, V.; Kočí, J.; Fořt, J.; Fiala, L.; Šál, J.; Hager, I.; Černý, R. Utilization of Crushed Pavement Blocks in Concrete: Assessment of Functional Properties and Environmental Impacts. Materials 2021, 14, 7361. https://doi.org/ $10.3390 /$ ma14237361

Academic Editors: Francisco Agrela and Alessandro P. Fantilli

Received: 14 October 2021

Accepted: 29 November 2021

Published: 30 November 2021

Publisher's Note: MDPI stays neutral with regard to jurisdictional claims in published maps and institutional affiliations.

Copyright: (c) 2021 by the authors. Licensee MDPI, Basel, Switzerland. This article is an open access article distributed under the terms and conditions of the Creative Commons Attribution (CC BY) license (https:/ / creativecommons.org/licenses/by/ $4.0 /)$.

\begin{abstract}
Production of concrete is connected to extensive energy demands, greenhouse gases production or primary sources depletion. Reflecting current economical, social, or environmental trends, there is strong pressure on mitigation these requirements and impacts. The exploitation of secondary- or waste materials in production processes has therefore a great potential which is not related solely to binders but also to fillers. In this light, this paper aims at thorough investigations of concrete mixtures with crushed concrete pavements as partial or full replacement of natural coarse aggregates. The research combines experimental techniques to quantify the influence of the substitution on basic physical, mechanical, and heat/moisture transport/storage parameters. The experimental data obtained are further exploited as input data for computational prediction of coupled heat and moisture transport to assess the influence of the aggregates substitution on hygrothermal performance of the built-in concretes. In the last step, the environmental impacts are assessed. Since the changes in the hygrothermal performance were found to be insignificant (i), the compressive strength were improved by up to $25 \%$ (ii) and most of the environmental impact indicators were decreased (iii) at the same time, the findings of the research presented predeterminate such a reuse strategy to wider application and use.
\end{abstract}

Keywords: recycled concrete aggregates; material properties; environmental impacts; hygrothermal performance; experimental analysis; computational modelling

\section{Introduction}

Being started by the Portland cement production patented in 1824 [1], concrete has become one of the most popular materials. Since the first batch had been mixed, concrete has made a huge progress that enabled literally unlimited possibilities in practical applications. Impressive mechanical properties, shape variability, availability of raw materials, reasonable price, high performance, or possibility of functional properties tailoring [2,3] can be stated as typical examples in that respect making concrete even more versatile and popular building material all over the world.

Similar to other fields of human activities, concrete industry has to reflect current trends. Being the most topical in the last years, the environmental protection efforts have probably the biggest impact these days. In this context, concrete has been branded as an ecohostile material whose production goes along with extensive carbon dioxide emissions [4,5], energy consumption [6], and primary sources depletion $[7,8]$. To reduce the environmental pressure that concrete is exposed to, some measures have been adopted being supposed to make it less harmful to the environment. A partial cement replacement by secondary 
products such as fly ash, slag, silica fume, and others $[8,9]$ represents the most significant step toward the reduction of energy demands as well as $\mathrm{CO}_{2}$ emissions. Utilization of byproducts or even waste materials turned out to be perspective also in case of fillers as it saves primary resources and reduces landfilling necessities, thus generally improving the overall life cycle indicators. Furthermore, from the point of view of the hydration and the structure formation processes, a substitution of the filler is easier as it is not as determining as that of the binder. There are therefore much more possibilities of what can be used [10].

Demolition waste can be considered as a very good candidate that acts like artificial aggregates [11]. According to Jin and Chen [12], up to 7 billion tons of concrete waste is produced every year and this number is still increasing. Being cleaned of impurities, as it might contain fibers or other types of organic and inorganic reinforcement [13], these aggregates exhibit very good mechanical properties, especially when concrete structures are the source of the waste [14]. Concrete slabs, bricks, or blocks from the pavements represent one of the most favorite sources as they are not provided with other constructing layers such as adhesives, renders, or finishes. Moreover, they do not contain any kind of reinforcements. They can be therefore considered as a secondary raw material of high quality, especially when high performance concrete is considered [15].

On the other hand, secondary- and waste materials might go along with some quality issues as their functional properties are usually not stable and may exhibit a significant variance when compared to primary sources. The final products exploiting such materials may then suffer the same issues. Based on that, building materials with waste or recycled components are supposed to represent a compromise between lower functional properties and increased environmental benefits and thus should be assessed in a complex way. A special attention must be also paid to energy demands related to the waste material extraction, purification, and modification prior to its application. Especially the crushing of materials with very high compressive strength (e.g., high performance concrete) might be more energy demanding. On the other hand, it might yield better functional properties.

Such an assessment is the main objective of this paper which aims at developing concrete with aggregates fully or partially replaced with the crushed concrete pavement blocks. The analysis of functional properties together with the quantification of environmental impacts is supposed to answer the question, whether the aforementioned compromise had been reached or one aspect only prevailed the other. Contrary to other paper focusing on that topic, this research is not strictly limited to only functional properties $[14,16]$ or environmental impacts investigations [17], but brings a complex insight to revise the reuse strategy in general. Beside the traditional experimental and environmental impact assessment approaches, the presented paper includes also a computational modelling prediction of the materials performance that should evaluate the usability of the newly developed ecofriendly mixture as a structural material.

\section{Materials and Methods}

\subsection{Materials}

The concrete studied is made of Portland cement CEM I 42.5 R (Malogoszcz, Poland) that is mixed with water to yield the $w / c$ ratio equal to 0.45 . The workability of the mixtures is further increased by an addition of plasticizers BASF BV 18 and BASF Glenium SKY 591. There is also fine and coarse aggregates of which type and amount differ in particular mixtures as summarized in Table 1. The natural aggregates originate from Dwudniaki, Poland (riverbed from Dunajec river), being formed mostly by sandstone $(40-50 \%)$, granite $(15-20 \%)$, porfire / melafire $(5-30 \%)$, and quartzite $(5-25 \%)$. The recycled aggregates are made of crushed concrete pavement blocks with compressive strength of $66.8 \mathrm{MPa}$, modulus of elasticity of $41.2 \mathrm{GPa}$, and bulk density of $2290 \mathrm{~kg} \cdot \mathrm{m}^{-3}$. The get the better overview, the particle size distribution curves of particular aggregates are depicted in Figure 1. The natural coarse aggregates is replaced either partially (REC50) or fully (REC100), being compared to the reference mixture (REF) without the recycled aggregates being contained. 
Table 1. Summary of mixture compositions.

\begin{tabular}{lccc}
\hline & REF & REC50 & REC100 \\
\hline CEM I 42.5 R $\left(\mathrm{kg} \cdot \mathrm{m}^{-3}\right)$ & 414.2 & 414.2 & 414.2 \\
Water $\left(\mathrm{kg} \cdot \mathrm{m}^{-3}\right)$ & 186.4 & 186.4 & 186.4 \\
Plasticizer BASF BV 18 (wt.\%) & 0.9 & 0.9 & 0.9 \\
Plasticizer BASF Glenium Sky 591 (wt.\%) & 1.4 & 1.4 & 1.4 \\
Natural fine aggregates 0/4 $\left(\mathrm{kg} \cdot \mathrm{m}^{-3}\right)$ & 615.1 & 280.6 & 569.2 \\
Natural coarse aggregates 2/8 $\left(\mathrm{kg} \cdot \mathrm{m}^{-3}\right)$ & 579.9 & 280.6 & - \\
Natural coarse aggregates 8/16 $\left(\mathrm{kg} \cdot \mathrm{m}^{-3}\right)$ & 562.3 & 264.1 & - \\
Recycled concrete aggregates 4/16 $\left(\mathrm{kg} \cdot \mathrm{m}^{-3}\right)$ & - & 825.3 & 1057.2 \\
\hline
\end{tabular}

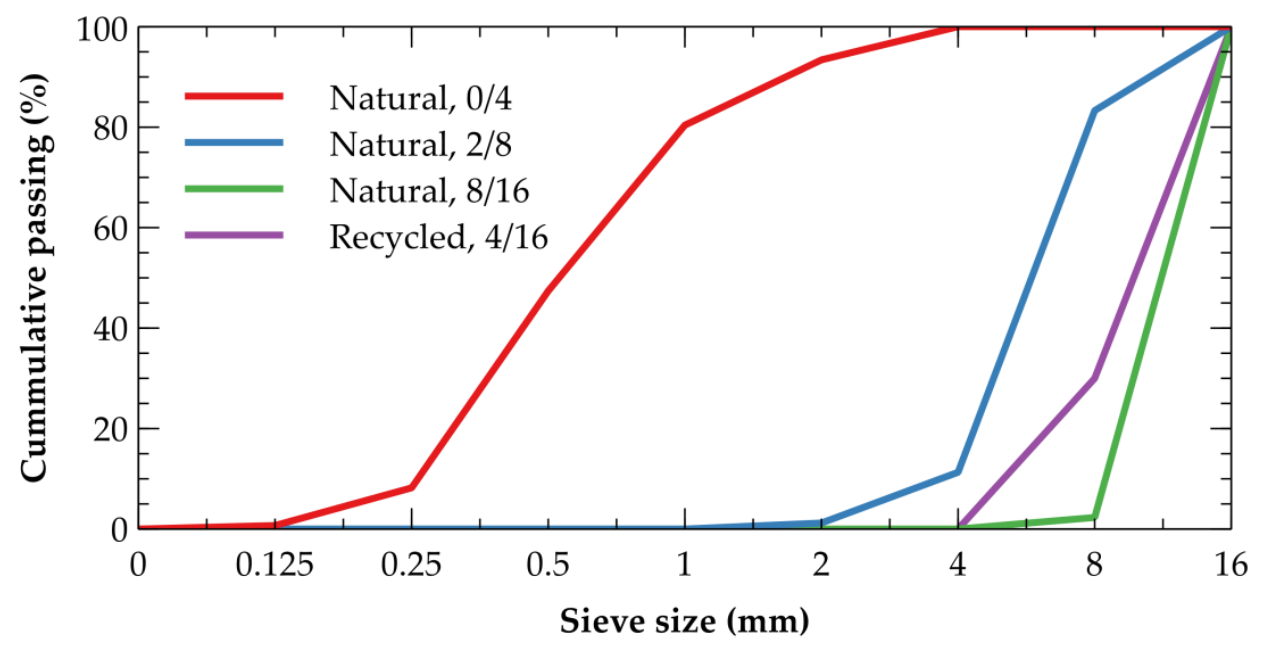

Figure 1. Particle size distribution curves of the aggregates used.

Recycled aggregate was made simply by crushing the concrete pavement blocks that were dismounted after exploitation period of 15 years (see Figure 2). The only modification was the sieving to achieve the particle size range demanded.
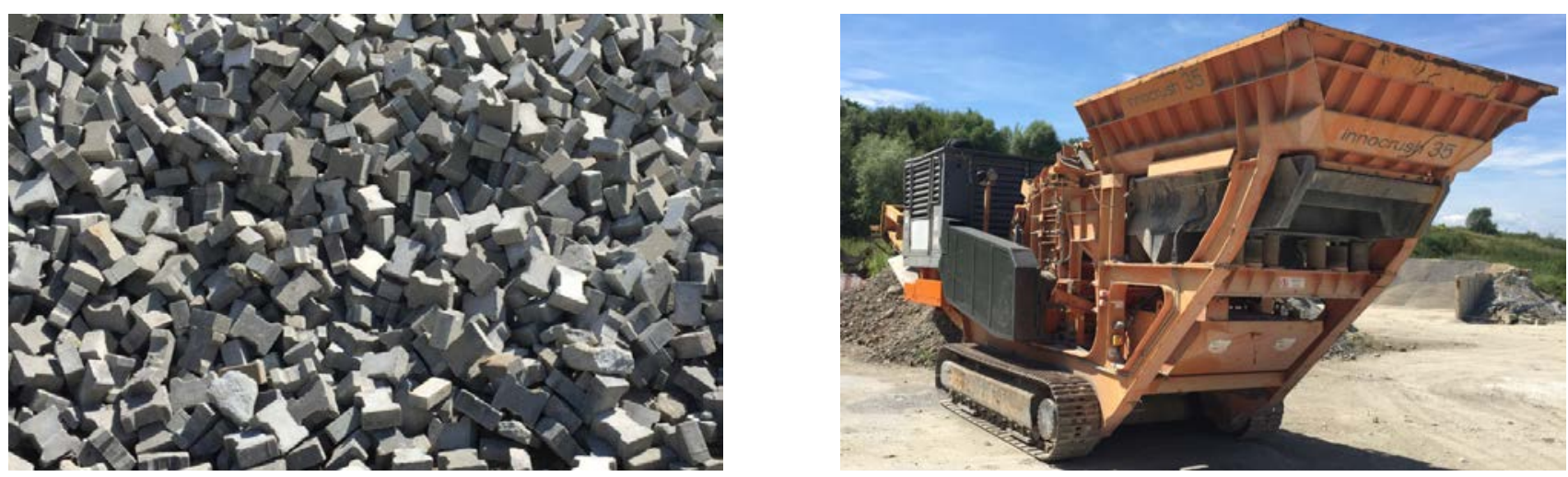

Figure 2. Concrete pavement blocks prior to their recycling (left) and the crushing device used for this purpose (right).

The individual fractions after the crushing and sieving procedures are shown in Figure 3 . Accounting for $24.59 \%$, the particles smaller than $4 \mathrm{~mm}$ were then rejected.

The concretes specimens were cast and stored in plastic cubic or cylindrical molds for the first $24 \mathrm{~h}$. After preliminary curing, water evaporation was prevented by covering them with plastic lids for 7 days. The specimens were then stored in natural air-drying conditions at the temperature of $(20 \pm 5){ }^{\circ} \mathrm{C}$ and relative humidity of $(50 \pm 5) \%$. 

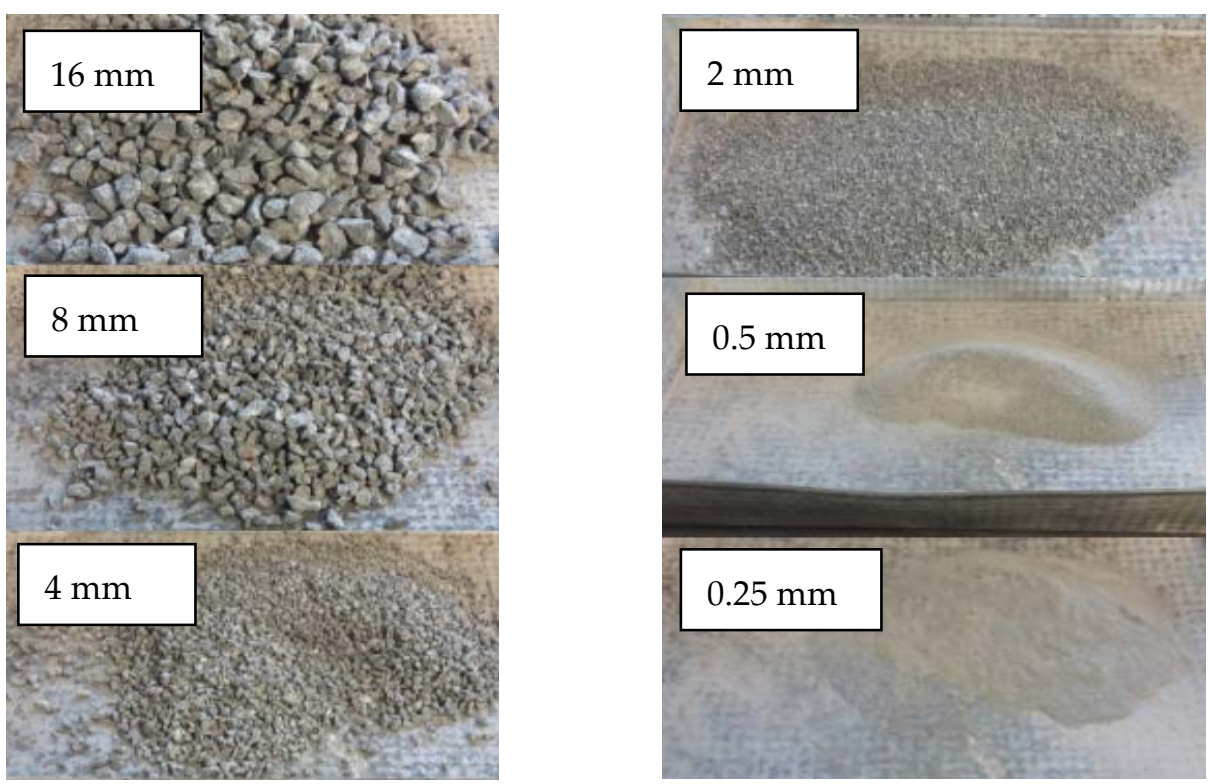

Figure 3. The individual fractions of the recycled coarse aggregates after sieving.

\subsection{Experimental Analysis}

Experimental analyses involved a determination of selected basic physical properties as well as heat and moisture storage and transport parameters to evaluate the influence of the recycled aggregates substitution on the functional properties of the concrete.

The bulk density was determined in a standard way [18] by averaging individual values obtained for a set of cubic samples (4 samples of $50 \times 50 \times 50 \mathrm{~mm}^{3}, 3$ samples of $\left.100 \times 100 \times 100 \mathrm{~mm}^{3}\right)$ and a set of prism samples $\left(3\right.$ samples of $40 \times 40 \times 150 \mathrm{~mm}^{3}$ ).

The heat transport and storage parameters represented by thermal conductivity and specific heat capacity, respectively, were obtained by means of transient heat pulse method using the ISOMET 2114 device (Applied Precision, Ltd., Bratislava, Slovakia). Contrary to the steady state methods defined in ČSN EN 12,664 [19], the dynamic method used provides almost instant results which is its biggest advantage. Even if the accuracy is not as high as in case of the standard steady state methods, the probes calibration according to ASTM D5334-14 [20] guarantees the correctness of the data obtained. Being equipped with a surface probe, the sample surface is heated up so that its thermal response can be recorded and evaluated. The measurements were conducted repeatedly on both, dry (nine times) and fully saturated samples (five times).

Following the principles given in ČSN EN ISO 12,572 [21], the water vapor transport parameters were analyzed and obtained by means of both dry-cup and wet-cup method, as depicted in Figure 4 for illustration.

Three samples of each mixture with dimensions of $100 \times 100 \times 30 \mathrm{~mm}^{3}$ were placed in the cups that contained either water or silica gel, depending on the type of arrangement, and the lateral sides were sealed to enable a one-dimensional moisture flux as the most dominant transport mode. Being placed in the climatic chamber with the controlled environment $\left(25^{\circ} \mathrm{C}, 50 \% \mathrm{RH}\right)$, the water vapor transport had been initiated and the mass change of the cup was continuously recorded. The water vapor diffusion resistance factor could then be expressed as

$$
\mu=\frac{D_{\mathrm{a}} \cdot M \cdot t \cdot S \cdot \Delta p_{\mathrm{v}}}{\Delta m \cdot d \cdot R \cdot T},
$$

where $D_{\mathrm{a}}=2.82 \times 10^{-5} \mathrm{~m}^{2} \cdot \mathrm{s}^{-1}$ is the water vapor diffusion coefficient in air at $25^{\circ} \mathrm{C}$, $M=0.01802 \mathrm{~kg} \cdot \mathrm{mol}^{-1}$ is the molar mass of water, $t(\mathrm{~s})$ is time, $S\left(\mathrm{~m}^{2}\right)$ is the cross-section area of the sample, $\Delta p_{\mathrm{v}}(\mathrm{Pa})$ is the partial pressure difference above and under the sample, 
$\Delta m(\mathrm{~kg})$ is the mass change, $d(\mathrm{~m})$ is the sample thickness, $R=8.314 \mathrm{~Pa} \cdot \mathrm{m}^{3} \cdot \mathrm{mol}^{-1} \cdot \mathrm{K}^{-1}$ is the gas constant, and $T(\mathrm{~K})$ denotes the temperature.

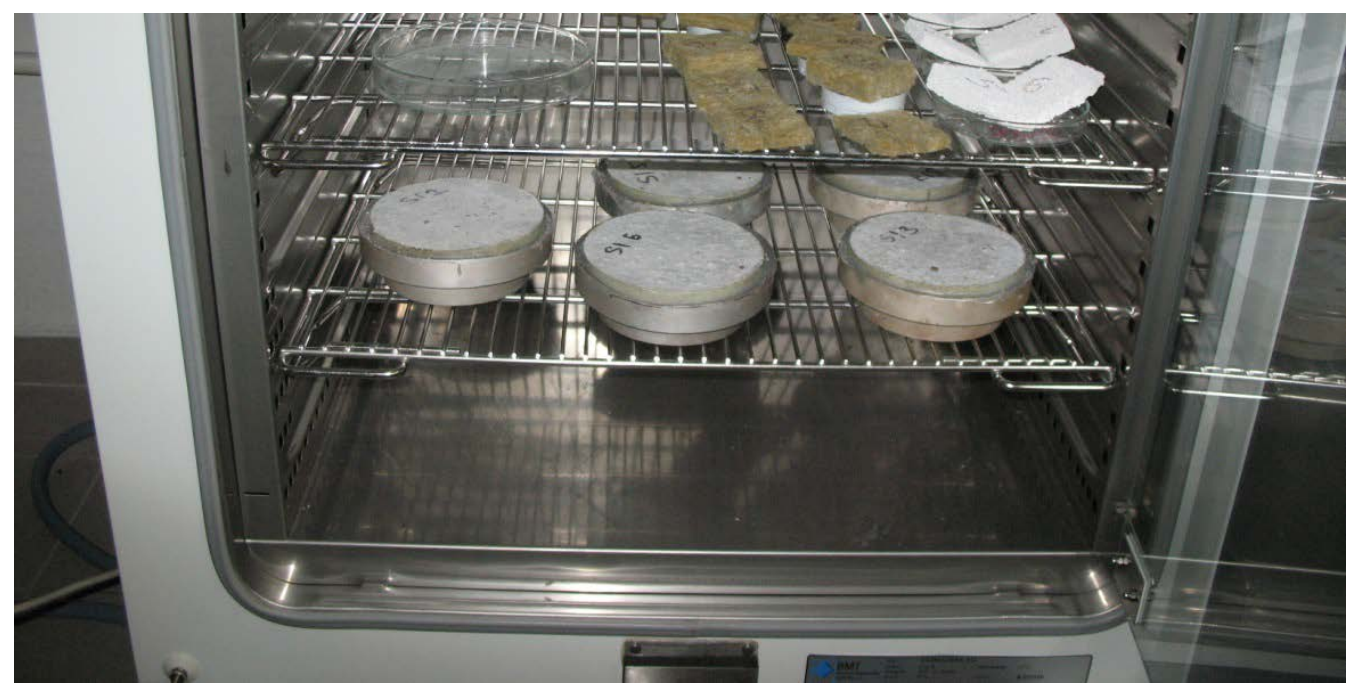

Figure 4. Cup method-placement of cups with samples in a climatic chamber with controlled environment.

Liquid water transport parameters were quantified using moisture diffusivity as a result of the vertical water sorption test [22,23]. Within the experimental procedure, the 50 $\times 50 \times 50 \mathrm{~mm}^{3}$ samples insulated on their lateral sides by epoxy resin were partially immersed in water to initiate the water suction due to capillary forces. Based on mass increase observed as a function of time, the apparent moisture diffusivity can be calculated as

$$
\kappa_{\text {app }}=\left(\frac{\Delta m}{S \cdot \sqrt{t} \cdot w_{\text {cap }}}\right)^{2},
$$

where $\Delta m(\mathrm{~kg})$ is the mass difference, $S\left(\mathrm{~m}^{2}\right)$ is the sample area in contact with water, $\sqrt{t}$ $\left(\mathrm{s}^{0.5}\right)$ is time, and $w_{\text {cap }}\left(\mathrm{kg} \cdot \mathrm{m}^{-3}\right)$ stands for the capillary moisture content. The scheme of the experiment is shown in Figure 5.

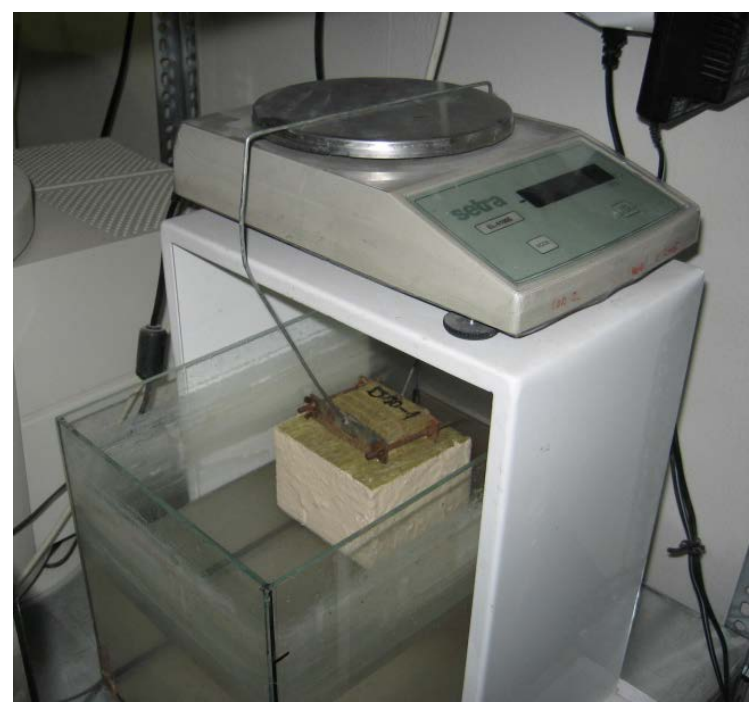

Figure 5. Experimental setup for the automatic measurements of water sorptivity. 
Water vapor storage parameters were represented by the hygroscopic moisture content defining a moisture content threshold after which the moisture is no longer stored in a water vapor- but only in a liquid form. According to common agreement [24] such a threshold corresponds to the equilibrium moisture content at $97 \% \mathrm{RH}$. Following this principle, four samples of each mixture were placed in a desiccator with supersaturated solution of $\mathrm{K}_{2} \mathrm{SO}_{4}$ that maintains the humidity of air above the solution at this level (see Figure 6). After the mass equilibrium of the samples had been reached, the moisture content was calculated gravimetrically.

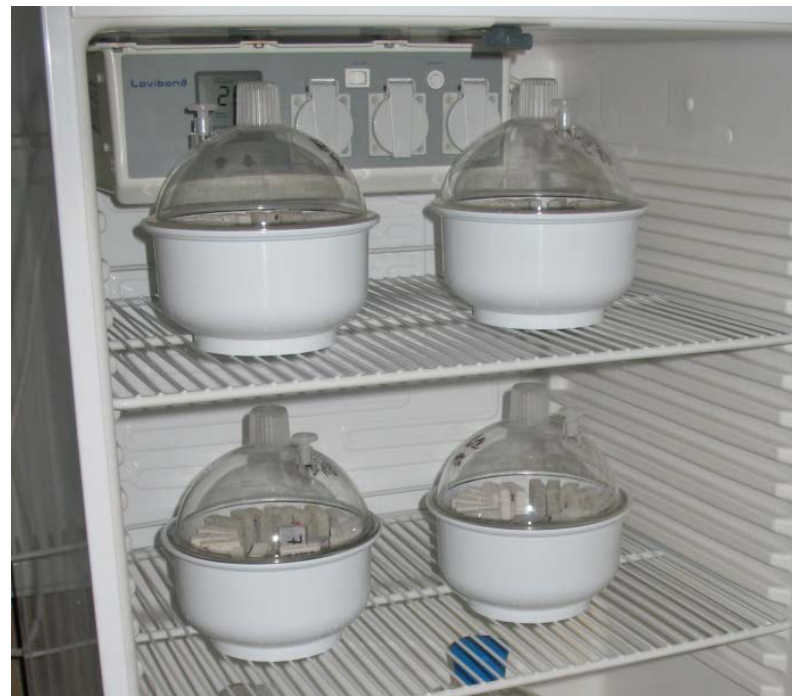

Figure 6. Desiccator method for measurement of the equilibrium moisture content at given relative humidity of environment.

The compressive strength and splitting tensile strength after 28 days and compressive strength after 90 days, were determined following the standard procedures for concrete defined in ČSN EN 12390-3 standard [25].

\subsection{Hygrothermal Performance}

Hygrothermal performance of the mixtures was compared by means of computational prediction of heat and moisture distribution over a reference year after exposure to dynamic weather conditions. A simplified construction segment (wall) was assumed for this purpose, being made of the concrete mixtures studied and provided with thermal insulation and finishes as shown in Figure 7.

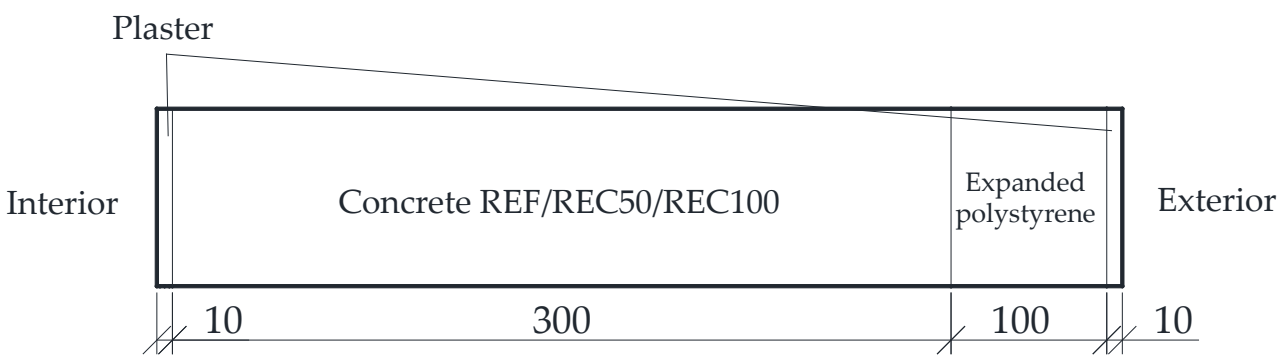

Figure 7. The scheme of the building segment analyzed.

The heat and moisture transport was computed using an advanced mathematical model of a diffusion type [26] that is able to precisely distinguish between particular phases of water that participate on the moisture transport at given conditions. The set of balance equation was solved numerically using the finite element method. As the input parameters, 
the material properties of concrete mixtures obtained experimentally were used, the other parameters of the thermal insulation and the plaster were taken from studies published previously $[27,28]$. The computational simulation resulted in the determination of hourly values of moisture content and temperature in every node of the computational mesh that together form the temperature and moisture distribution fields and can be further post-processed to get an overview on the hygrothermal performance. The boundary conditions on the exterior side were represented by the test reference year for Ostrava, Czech Republic [29], containing long-term average hourly values of selected weather parameters (temperature, relative humidity, rainfalls, wind velocity, wind direction, direct solar radiation, diffuse solar radiation). The interior boundary conditions were set to $21^{\circ} \mathrm{C}$ and $55 \%$ of relative humidity according to the thermal standard [30].

\subsection{Environmental Impact Assessment}

The LCA (life cycle assessment) methodology was used to perform the environmental analysis of concrete mixtures studied, which considers each manufacturing step and quantifies all the benefits following the ČSN EN ISO 19,011 [31] and ČSN EN ISO 14,044 [32] standards. All the results presented within this subtask are related to the functional unit which is $1 \mathrm{~m}^{3}$.

The analysis considers two scenarios which are combined to accommodate all the mixtures studied [33]. The natural resources scenario contemplates quarrying of granite/limestone, loading, two-stage crushing, loading, and transportation between particular stages. According to Borghi et al. [34], transportation distances for the natural aggregates were assumed to be $30 \mathrm{~km}$. The recycling scenario contemplates the concrete pavement blocks at the end-of-life which must be collected, crushed, and sieved and transported to a concrete plant where it can be used as the filler. Within this scenario, the material needs to be transported about $60 \mathrm{~km}$ together including its collection and consequent delivery to the concrete plant [34].

The life cycle impact assessment performed was based on the IMPACT 2002+ methodology, which is very frequently used among researchers and environmentalists (see $[35,36]$ ). Following midpoint indicators were used to compare the particular mixtures studied: carcinogens (CA), non-carcinogens (NCA), respiratory organics (RO) and inorganics (RI), aquatic (AE) and terrestrial ecotoxicity (TE), terrestrial acidification/nitrification (TA/N), aquatic acidification (AC) and eutrophication (AEU), land occupation (LO), mineral extraction (ME), non-renewable energy (NRE), ionizing radiation (RI), ozone layer depletion (OLD), and global warming (GW). To depict the environmental burden of materials studied, the endpoint level categories including Human Health, Ecosystem Quality, Climate change, and Resources consumption were determined. All the data gathered to perform the analysis were obtained using the Simapro 8.5 software and Ecoinvent database 3.5.

Since the original material replacement may result in changes in the functional performance, the combined environmental/functional assessment derived from Pedreno-Rojas et al. [37] was employed to access more reliable comparison of studied materials. The overall environmental/functional efficiency, $E_{\mathrm{c}}$, expresses the environmental costs per unit compressive strength (3), being represented by the weighted endpoint environmental single score:

$$
E_{\mathrm{c}}=\frac{E}{R_{\mathrm{c}}},
$$

where $E(\mathrm{mPt})$ is the normalized environmental single score, and $R_{\mathrm{c}}(\mathrm{MPa})$ the compressive strength after 28 and 90 days of curing, respectively.

\section{Results and Discussion}

The evaluation of the concrete mixtures with natural coarse aggregates replaced partially or fully is done independently from three different point of views. The individual results are then compared and discussed, forming the complex evaluation of the reuse strategy, as depicted in Figure 8 for a better comprehensibility. 


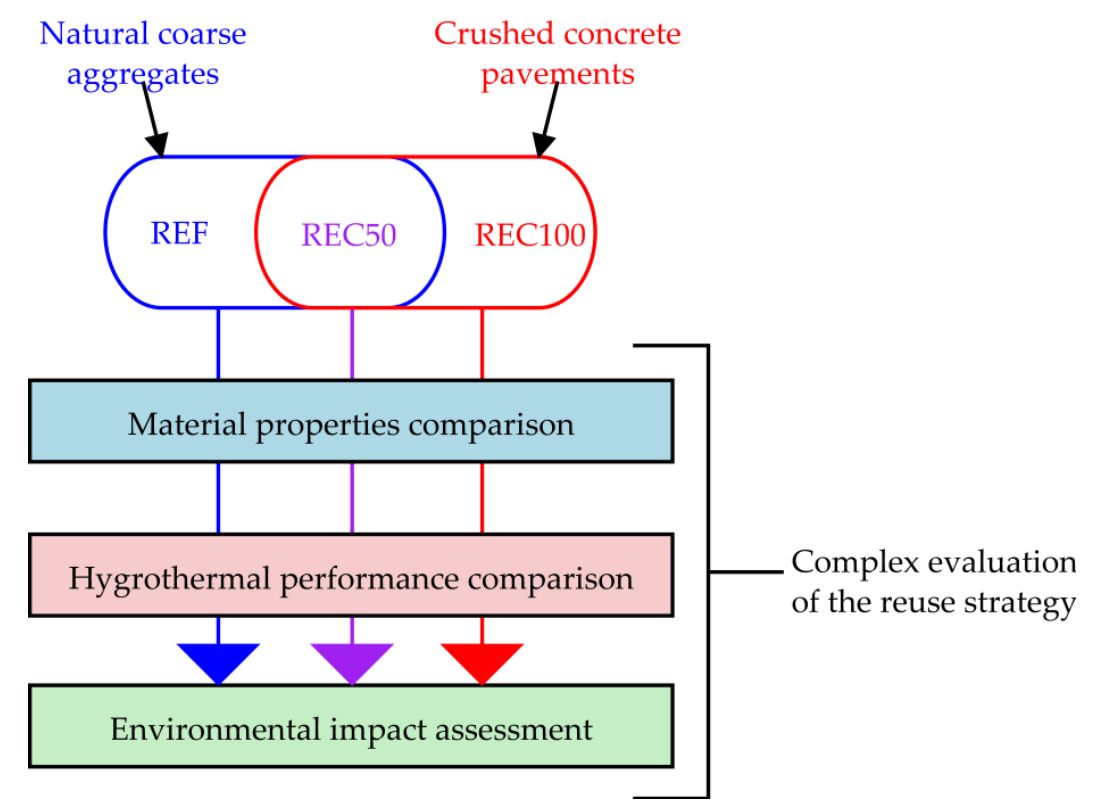

Figure 8. Scheme of the complex assessment of the reuse strategy.

\subsection{Materials Properties}

Only slight changes were found in bulk density values after the coarse aggregate in the reference mixture was replaced. While the bulk density of REF was $2236 \mathrm{~kg} \cdot \mathrm{m}^{-3}$, the partialas well as the full replacement of the aggregates resulted in a decrease to $2192 \mathrm{~kg} \cdot \mathrm{m}^{-3}$, which is less than $2 \%$. The difference might indicate some changes in the structure and the porosity of the REC50 and REC100 samples compared to the REF sample. Being within the measurement uncertainty range $(\sim 3 \%)$, however, deeper conclusions cannot be formulated based on the difference recognized. Anyway, the very low sorptivity of the natural coarse aggregates from Dwudniaki, Poland $(2.5 \%$ for $2 / 8$ and $2.3 \%$ for $8 / 16)$ [38] indicates that this natural raw material is more dense than concrete pavement blocks after 15 years of exploitation ( $\sim 5 \%$ as published by Krawczyk et al. [39]). In this light, the porosity increase and bulk density decrease seems to be logical and justifiable, especially when it correlates to the water absorption values: REF-5.2\%, REC $50-5.8 \%$, and REC $100-6.7 \%$.

The similar trend can be confirmed also by means of a comparison of thermal transport and storage properties, being summarized in Table 2.

Table 2. Thermal transport and storage properties.

\begin{tabular}{lcccc}
\hline & & REF & REC50 & REC100 \\
\hline \multirow{2}{*}{ Thermal conductivity $\left(\mathrm{W} \cdot \mathrm{m}^{-1} \cdot \mathrm{K}^{-1}\right)$} & dry & 2.41 & 1.84 & 2.08 \\
Specific heat capacity & saturated & 2.79 & 2.30 & 2.29 \\
\hline
\end{tabular}

Here, the decrease of thermal conductivity of REC50 and REC100, up to $23.7 \%$ depending on type of samples and its moisture conditions, can be understood as a clear evidence of the porosity increase. More dense specimens exhibit also higher specific heat capacity, which is also confirmed by the results presented in the table above. Last but not the least, it is important to realize that the differences found are very small which make them prone to be affected by the experimental uncertainties.

The hygric properties of the samples presented in Table 3 might seem contradictory at the first glance when compared to basic physical and thermal properties. Usually, more porous materials exhibit higher permeability or water vapor transport parameters. In this case, however, the water vapor diffusion resistance factor values of REC50 and REC100 
samples are higher than those of REC which makes these materials less permeable (see Table 3).

Table 3. Moisture transport and storage properties.

\begin{tabular}{|c|c|c|c|c|}
\hline & & REF & REC50 & REC100 \\
\hline \multirow{2}{*}{ Water vapor diffusion resistance factor (-) } & dry-cup & 89.3 & 124.3 & 131.0 \\
\hline & wet-cup & 42.9 & 58.6 & 66.6 \\
\hline Sorption capacity at $97 \%\left(\mathrm{~m}^{3} \cdot \mathrm{m}^{-3}\right)$ & & 9.09 & 10.99 & 10.49 \\
\hline Moisture diffusivity $\left(\mathrm{m}^{2} \cdot \mathrm{s}^{-1}\right)$ & & $7.13 \times \cdot 10^{-9}$ & $1.58 \times \cdot 10^{-8}$ & $1.46 \times \cdot 10^{-9}$ \\
\hline
\end{tabular}

The different water vapor transport properties can be ascribed to various phenomena. It is important to realize that aggregates do not represent primarily the main transport paths for the water vapor. The substitution of the natural aggregates by the crushed concrete should be therefore insignificant, as the bonding matrix covers this type of mass transport. On the other hand, crushed concrete has higher sorption capacity as shown in Table 3, therefore it might partially reduce the amount of water vapor transported through the samples and thus decrease its permeability. Last but not the least, unlike natural aggregates which is inert, the crushed concrete might be still involved in the hydration processes which might result in the formation of more dense structure. A deeper characterization of the bonding matrix as well as an investigation of the pore space characteristics might provide the explanation. Unfortunately, it is beyond the scope of this paper and will be published separately within the future research on this topic. Anyway, it can be stated in general, that all the samples studied are relatively low moisture-conductive as their water vapor diffusion resistance factor is high and the moisture diffusivity values are about $\sim 10^{-9} \mathrm{~m}^{2} \cdot \mathrm{s}^{-1}$.

The procedure of mechanical properties testing, namely the splitting tensile strength test, is depicted in Figure 9 and the results are summarized in Table 4.
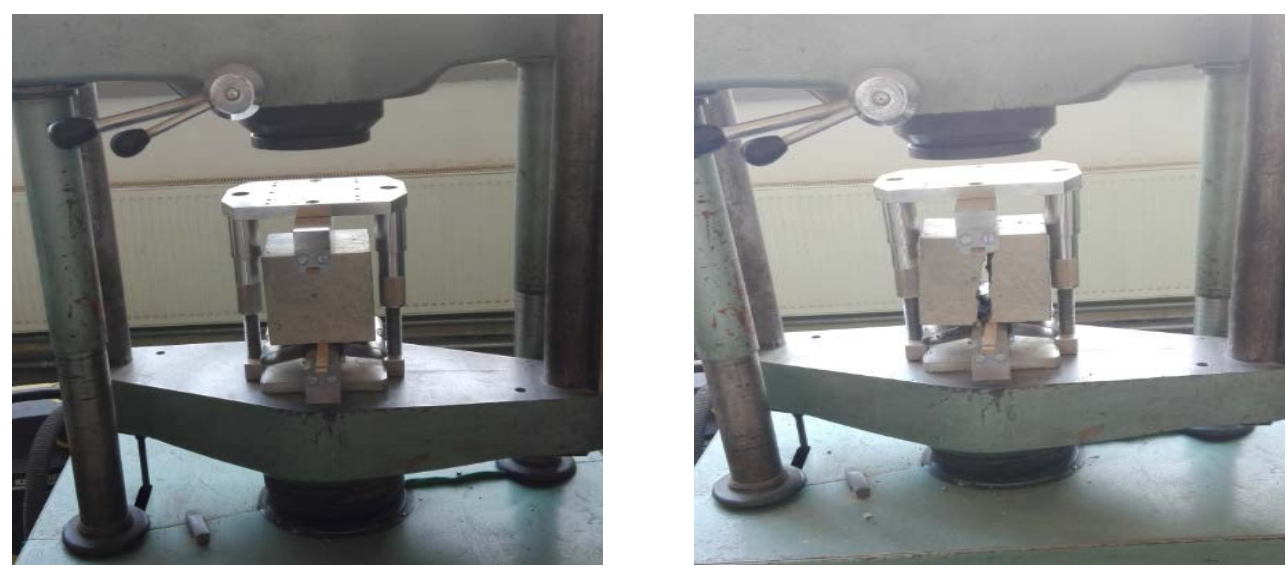

Figure 9. The splitting tensile strength test: a samplebefore (left) and after (right) the testing procedure.

Table 4. Mechanical properties.

\begin{tabular}{lcccc}
\hline & & REF & REC50 & REC100 \\
\hline Compressive strength (MPa) & 28 days & 46.1 & 56.8 & 54.5 \\
Splitting tensile strength (MPa) & 90 days & 52.2 & 65.2 & 64.0 \\
\hline
\end{tabular}

It is clear, that all the mechanical parameters observed were increased after the partial or full replacement of the natural coarse aggregates. The highest increase, $\sim 24.9 \%$, was 
found in 90-day compressive strength of the REC50. Generally, there are many factors affecting the compressive strength after the natural coarse aggregate substitution and their investigation would require separate research paper as presented e.g., by Xuan et al. [40], which is beyond the scope of this research. In this case, the shape of coarse particles might play a significant role as the crushed recycled coarse aggregates with sharp edges exhibiting lower compressibility contrary to the natural aggregates (riverbed gravel) whose edges are rather round (see Figure 10). The bonding ability of the aggregates to the cement matrix represents another key factor in that respect. It can be expected that the recycled aggregates have a higher bonding potential than the natural aggregates which have significantly smoother surface. Unfortunately, the authors do not possess the SEM images that could support or disprove such a hypothesis.
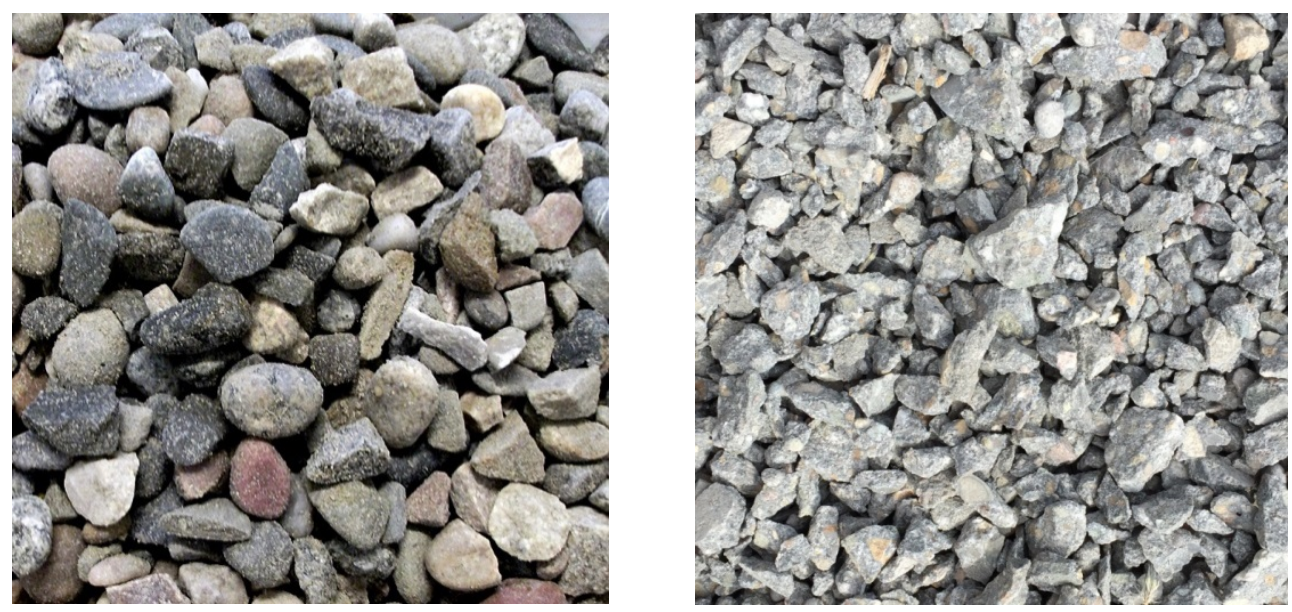

Figure 10. The visual comparison of particles of the natural (left) and recycled (right) coarse aggregates.

\subsection{Hygrothermal Performance}

Based on the material parameters summarized in Section 3.1 and their similarity, in particular, it can be expected that the substitution of coarse aggregates is not predisposed to affect the hygrothermal performance of the designed materials significantly. On the other hand, the dynamic boundary conditions on the exterior side of the wall assembly together with different storage and transport properties of particular mixtures can be exhibited unpredictably, so the computational modelling can be used as an effective tool to reveal possible shortages of the materials studied.

Both external layers, the thermal insulation and the exterior finish, assumed in the composition of the wall assembly act like a buffer that mitigates the impacts of weather conditions. In the light of this fact, the thermal performance of the assemblies is almost identical. The highest difference within the reference year was found in a point $110 \mathrm{~mm}$ under the surface. As of 12 January of the reference year, this difference was only $0.383^{\circ} \mathrm{C}$ as depicted in Figure 11.

The hygric performance of the particular assemblies studied differ more than the previously showed temperature performance. However, even in this case, the differences are still very small. The Figure 12 compares the relative humidity profiles as of 27 January of the reference year, where the highest difference was found $(2.2 \%)$ in the point $17 \mathrm{~mm}$ under the exterior surface. Since the outer layers (thermal insulation, plaster) act like a buffer and reduce the response of the base material, the hygrothermal performance of particular concrete mixtures is almost identical and some changes were found only in these layers which are exposed to the dynamic boundary conditions in the most extensive way. 


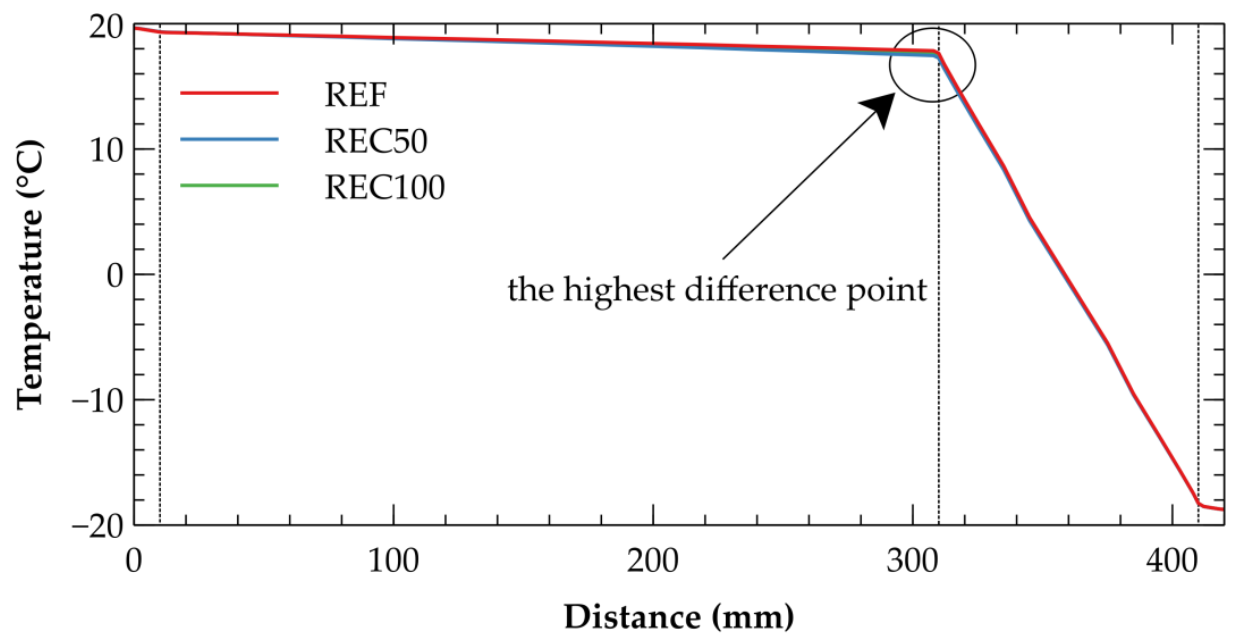

Figure 11. Comparison of temperature profiles as of 12 January of the reference year. The position 0 $\mathrm{mm}$ denotes the interior side of the wall, the position $420 \mathrm{~mm}$ denotes the exterior side.

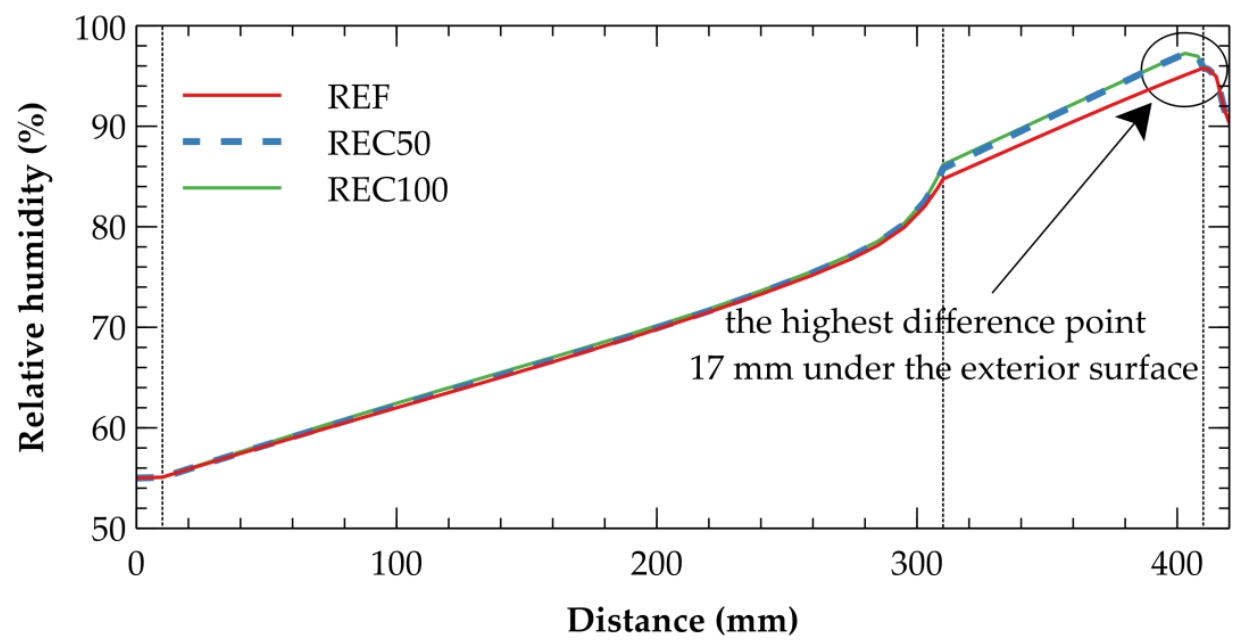

Figure 12. Comparison of relative humidity profiles as of 27 January of the reference year. The position $0 \mathrm{~mm}$ denotes the interior side of the wall, the position $420 \mathrm{~mm}$ denotes the exterior side.

Based on the results of the hygrothermal performance described above it can be concluded that all the mixes studied showed a very similar performance as the highest difference found within the applied reference year was only $0.4{ }^{\circ} \mathrm{C}$ and $2.2 \%$ of $\mathrm{RH}$, respectively. It means, the substitution of the natural coarse aggregates by the crushed concrete pavements does not have any (negative) effect on the heat and moisture distribution. Such a finding predisposes this measure (aggregates substitution) to be recommended as it might bring other benefits while the performance is not affected. The evaluation of environmental impacts is therefore given in Section 3.3.

\subsection{Environmental Impact Assessment}

Based on the mixtures compositions and the natural-resources/recycling scenarios, the values of particular midpoint indicators are summarized in Table 5.

It can be stated, based on the data presented in Table 3, that utilization of crushed concrete pavements resulted in substantial improvement of most of the indicators evaluated. The highest improvement can be observed in a reduction of aquatic eutrophication and terrestrial acidification/nitrification. A substantial decrease in mineral extraction refers to the preservation of natural resources owing to waste material valorization. Among both recycling scenarios, the complete substitution of the natural aggregates (REC100) provided 
more favorable results, which can be assigned to less demanding processing. Considering the calculated results for global warming with regard to the carbon dioxide equivalent, all scenarios achieved similar values and only minor improvement was delivered as the process of recycling involves crushing, in particular, energy is very demanding and therefore is negatively reflected in the resulting numbers. On the other hand, only a few indicators refer to an increased negative impact on the natural environment. As concluded by Borghi et al. [34], the replacement of aggregates in concrete does not provide a significant reduction in carbon dioxide production since the longer transportation distance shifted the diesel consumption.

Table 5. Results of assessment of environmental impacts—selected midpoint indicators.

\begin{tabular}{llccc}
\hline & \multicolumn{1}{c}{ Unit } & REF & REC50 & REC100 \\
\hline Carcinogens (CA) & $\mathrm{kg} \cdot \mathrm{C}_{2} \mathrm{H}_{3} \mathrm{Cl} \cdot \mathrm{eq}$ & 0.207928 & 0.181762 & 0.160954 \\
Non-carcinogens (NCA) & $\mathrm{kg} \cdot \mathrm{C}_{2} \mathrm{H}_{3} \mathrm{Cl} \cdot \mathrm{eq}$ & 0.376624 & 0.389560 & 0.305319 \\
Respiratory organics (RO) & $\mathrm{kg} \cdot \mathrm{C}_{2} \mathrm{H}_{4} \cdot \mathrm{eq}$ & 0.080252 & 0.071736 & 0.06861 \\
Respiratory inorganics (RI) & $\mathrm{kg} \cdot \mathrm{PM}_{2.5} \cdot \mathrm{eq}$ & 0.032686 & 0.031078 & 0.029436 \\
Aquatic ecotoxicity (AE) & $\mathrm{kg} \cdot \mathrm{TEG} \cdot \mathrm{water}$ & 1235.460 & 1418.594 & 1020.719 \\
Terrestrial ecotoxicity (TE) & $\mathrm{kg} \cdot \mathrm{TEG} \cdot \mathrm{soil}$ & 915.9246 & 793.4930 & 521.3207 \\
Terrestrial acidification/nitrification (TA/N) & $\mathrm{kg} \cdot \mathrm{SO}_{2} \cdot \mathrm{eq}$ & 2.372920 & 2.243352 & 2.181528 \\
Aquatic acidification (AC) & $\mathrm{kg} \cdot \mathrm{SO}_{2} \cdot \mathrm{eq}$ & 0.489180 & 0.463767 & 0.453614 \\
Aquatic eutrophication (AEU) & $\mathrm{kg} \cdot \mathrm{PO}_{4} \cdot \mathrm{P}-\mathrm{lim}$ & 0.002552 & 0.001765 & 0.001274 \\
Land occupation (LO) & $\mathrm{m} \cdot \mathrm{a}$ & 0.936772 & 1.125691 & 0.813272 \\
Mineral extraction (ME) & $\mathrm{MJ} \cdot \mathrm{surplus}^{2}$ & 0.686285 & 0.514924 & 0.390787 \\
Non-renewable energy (NRE) & $\mathrm{MJ} \cdot \mathrm{primary}^{-14} \cdot \mathrm{eq}$ & 807.8142 & 816.8235 & 762.527 \\
Ionizing radiation (RI) & $\mathrm{Bq} \cdot \mathrm{C}^{-14} \cdot \mathrm{eq}$ & 384.3772 & 304.4095 & 262.7194 \\
Ozone layer depletion (OLD) & $\mathrm{kg} \cdot \mathrm{CFC}^{-11} \cdot \mathrm{eq}$ & $9.86 \times 10^{-6}$ & $1.01 \times 10^{-5}$ & $9.47 \times 10^{-6}$ \\
Global warming (GW) & $\mathrm{kg} \cdot \mathrm{CO}_{2} \cdot \mathrm{eq}$ & 168.6626 & 168.5723 & 165.6829 \\
\hline
\end{tabular}

For a better interpretation, the obtained results are displayed graphically in Figure 13, referring to REF mixture by means of relative change expression.

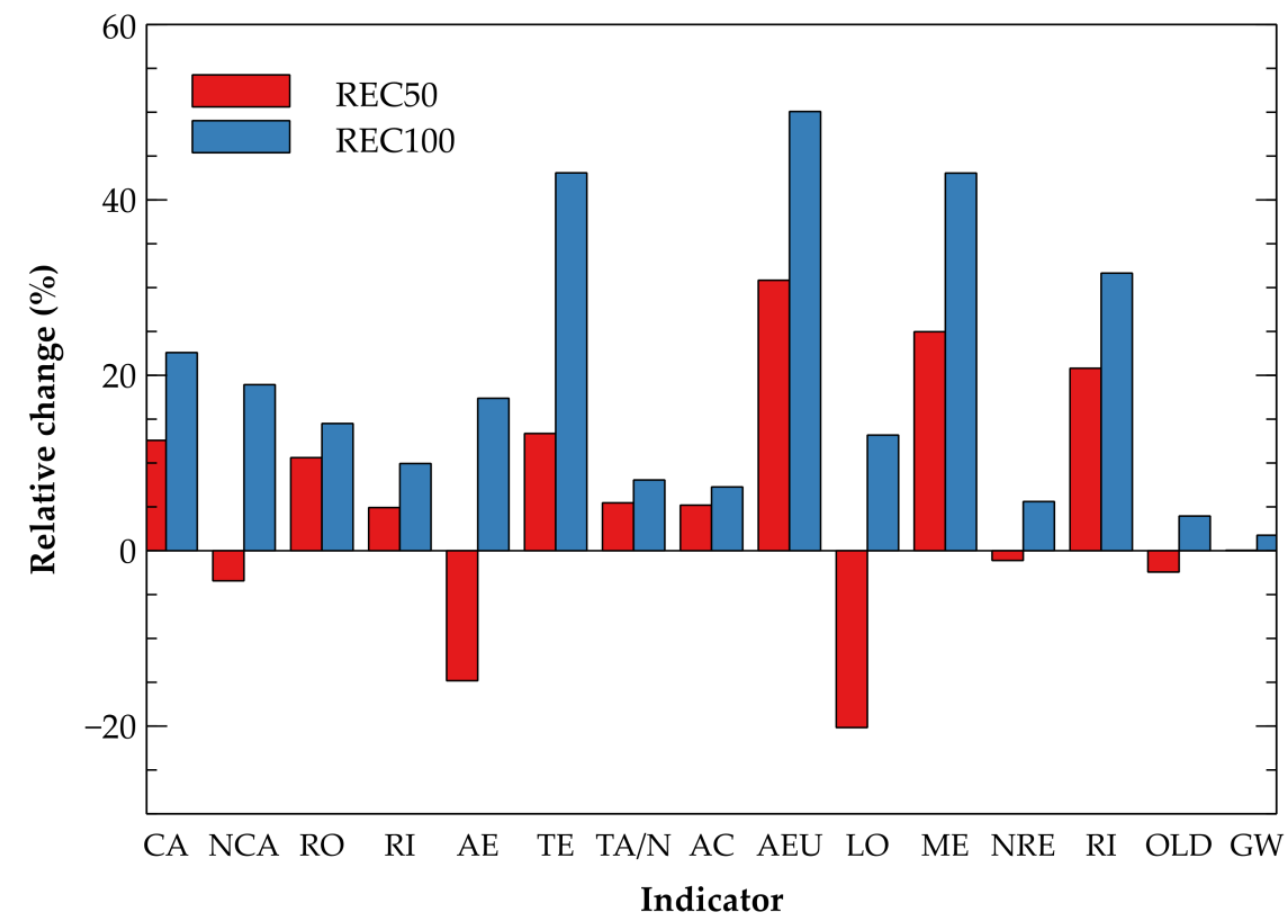

Figure 13. Relative change of the environmental indicators-recycling scenarios. 
Since the midpoint level consists of many categories, the endpoint comparison is accessed in Figure 14 to depict the environmental implications in a more comprehensible way. As depicted in this figure, the most intense negative consequences of the materials production are associated with climate change. It arises from the energy-demanding production of cement and carbon dioxide emissions during the decomposition of limestone rock. It is obvious, such a share is almost equal for all mixtures. The results of the combined environmental/functional assessment provided in Table 6 show the environmental costs expressed by the cumulative endpoint score per MPa of the compressive strength after 28 and 90 days, respectively. In the light of the improved mechanical performance of designed mixtures REC50 and REC100 with reduced environmental burden, one can see significantly improved environmental efficiency for both mixtures. Here, the environmental costs $E_{\mathrm{c}}$ was decreased by up to $20 \%$ at 28 days and by $17 \%$ at 90 days, compared to the reference mixture. Both mixtures REC50 and REC100, differ only very slightly and notable variations were not observed. Contrary to the studies published previously [41,42], the effectiveness of the environmental burden mitigation is more distinct due to concurrent improvements in the mechanical strength and reduced environmental loads.

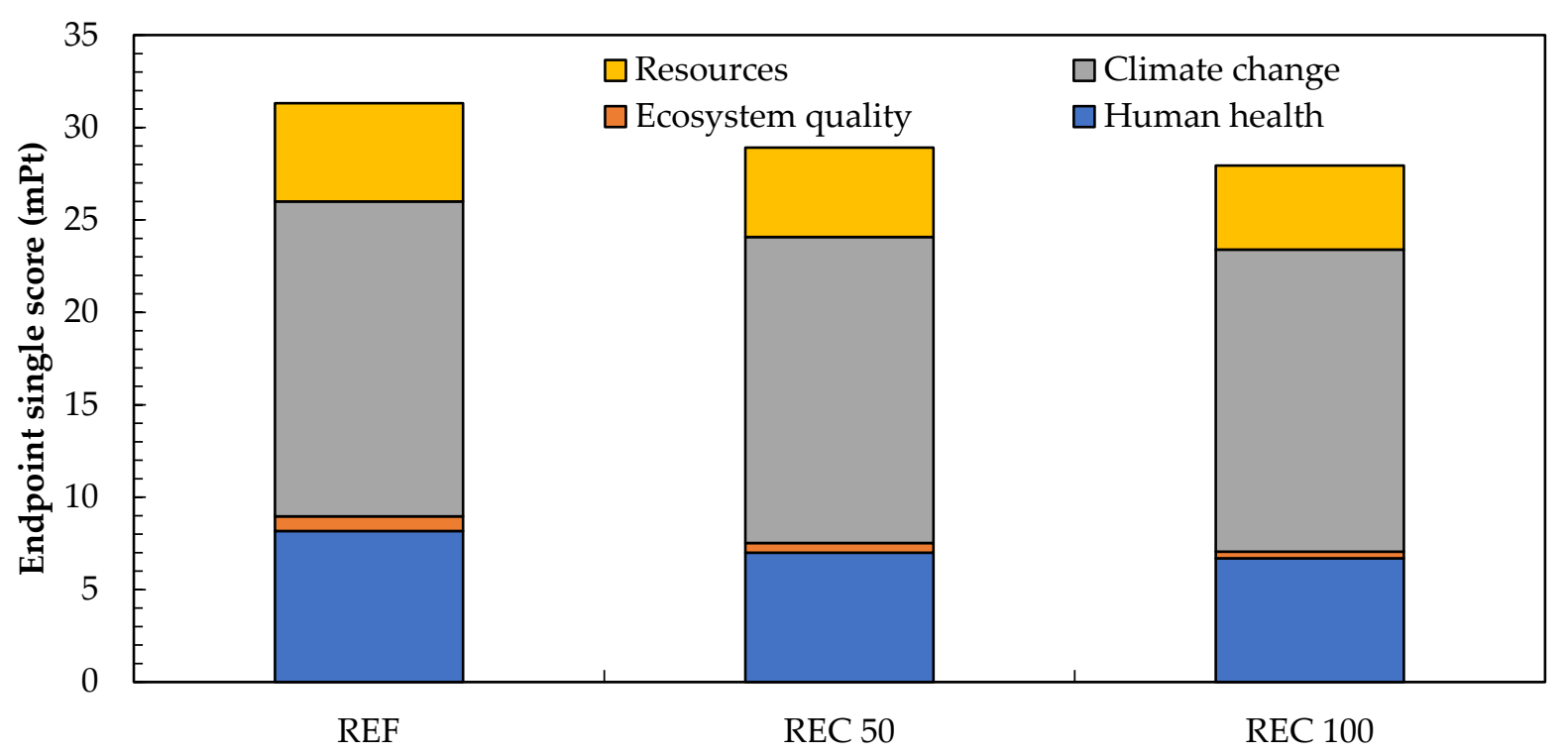

Figure 14. Endpoint categories comparison of the crushed pavements recycling scenarios.

Table 6. Results of the combined environmental/functional performance.

\begin{tabular}{ccc}
\hline \multirow{2}{*}{ Mixture } & \multicolumn{2}{c}{ Environmental Costs $E_{\mathbf{c}}(\mathbf{m P t} / \mathbf{M P a})$} \\
\cline { 2 - 3 } & $\mathbf{2 8}$ Days & $\mathbf{9 0}$ Days \\
\hline REF & 0.6793 & 0.5999 \\
REC50 & 0.5091 & 0.4435 \\
REC100 & 0.5128 & 0.4366 \\
\hline
\end{tabular}

\section{Conclusions}

The research presented in this paper deals with a complex investigation of concrete mixtures with crushed concrete pavements used as a partial or full replacement of natural coarse aggregates. Such a substitution reflects the main global strategies and efforts that strive to decrease the energy demands, preserve the primary sources, or protect the environment in general to reach sustainable development. Within the light of the aforementioned efforts, this research aims at a thorough investigation of the mixtures designed to assess their material properties and hygrothermal performance as well as to quantify their contribution to mitigation of negative environmental impacts. 
The thorough experimental analyses of basic physical, heat and moisture transport, and storage parameters revealed that the substitution of the natural coarse aggregates for crushed concrete pavements at the end of their service life did not influence the material properties in a negative way. It was found, on the contrary, that an increase of porosity was positively reflected in a decrease of thermal conductivity of the new mixtures by up to $23.7 \%$, which predisposed them to achieve better thermal performance when used e.g., in building constructions. On the other hand, such an advantage can be neglected by the presence of thermal insulation in the assembly as demonstrated in the example exploiting computational modelling of coupled heat and moisture transport to predict the hygrothermal performance of construction segments. Here, the highest differences between particular materials accounted only for $0.4{ }^{\circ} \mathrm{C}$ and $2.2 \%$ of relative humidity, respectively, within a reference year. It indicates, in any case, that the hygrothermal performance of the concrete is not negatively affected after the aggregates substitution.

In the last field of the investigation, the analysis of environmental impacts confirmed a positive contribution of the recycling scenarios to the environmental protection as most of the indicators observed showed favorable changes. The most significant contribution can be found, among others, in mitigation of aquatic eutrophication (by up to $50.08 \%$ ), terrestrial ecotoxicity (by up to $43.08 \%$ ), or mineral extraction (by up to $43.06 \%$ ). In general, the full replacement scenario showed more valuable results than the partial replacement.

Based on the complex assessment (material properties, hygrothermal performance, and environmental analysis) of concrete with various levels of crushed concrete pavements it can be concluded that the full replacement of natural coarse aggregates does not negatively affect neither their material properties nor their hygrothermal performance. On the other hand, since this measure goes along with positive changes in environmental impacts, crushed concrete pavements as the filler can be highly recommended. The results obtained proved that utilization of crushed pavements as natural aggregate replacement provides notable benefits in terms of sustainable assessment of building materials as described before. Notwithstanding, our study points to the overall favorable effects associated with crushed pavements reuse. Improvements in the mechanical strength together with lowered environmental impact predeterminate such reuse strategy to wider application and use.

Author Contributions: Conceptualization, V.K.; methodology, V.K., J.K., L.F., J.F. and I.H.; software, J.F.; validation, V.K., J.K. and I.H.; formal analysis, R.Č.; investigation, V.K., J.K., L.F.; resources, I.H.; data curation, V.K. and J.Š.; writing—original draft preparation, V.K.; writing-review and editing, R.Č.; visualization, V.K.; supervision, R.Č.; project administration, I.H.; funding acquisition, I.H., J.Š. and R.Č. All authors have read and agreed to the published version of the manuscript.

Funding: This research has been supported by the Grant Agency of the Czech Technical University in Prague under project No. SGS19/143/OHK1/3T/11, by EMMAT project E-mobility and sustainable materials and technologies PPI/APM/2018/00027 financed by the Polish National Agency for Academic Exchange (NAWA) and by the Integral Grant Agency of the Institute of Technology and Business in Ceske Budejovice under grant No. 8210-009.

Institutional Review Board Statement: Not applicable.

Informed Consent Statement: Not applicable.

Data Availability Statement: The data presented in this study are available on request from the corresponding author.

Conflicts of Interest: The authors declare no conflict of interest.

\section{References}

1. Courland, R.; Smith, D. Concrete Planet: The Strange and Fascinating Story of the World's Most Common Man-Made Material; Prometheus Books: Amherst, NY, USA, 2011.

2. Bautista-Gutierrez, K.P.; Herrera-May, A.L.; Santamaría-López, J.M.; Honorato-Moreno, A.; Zamora-Castro, S.A. Recent progress in nanomaterials for modern concrete infrastructure: Advantages and challenges. Materials 2019, 12, 3548. [CrossRef]

3. Pasztetnik, M.; Wróblewski, R. A literature review of concrete ability to sustain strength after fire exposure based on the heat accumulation factor. Materials 2021, 14, 4719. [CrossRef] 
4. Stafford, F.N.; Raupp-Pereira, F.; Labrincha, J.; Hotza, D. Life cycle assessment of the production of cement: A Brazilian case study. J. Clean. Prod. 2016, 137, 1293-1299. [CrossRef]

5. Shen, W.; Cao, L.; Li, Q.; Zhang, W.; Wang, G.; Li, C. Quantifying $\mathrm{CO}_{2}$ emissions from China's cement industry. Renew. Sustain. Energy Rev. 2015, 50, 1004-1012. [CrossRef]

6. Madlool, N.; Saidur, R.; Hossain, M.; Rahim, N.A. A critical review on energy use and savings in the cement industries. Renew. Sustain. Energy Rev. 2011, 15, 2042-2060. [CrossRef]

7. Brocklesby, M.; Davison, J. The environmental impacts of concrete design, procurement and on-site use in structures. Constr. Build. Mater. 2000, 14, 179-188. [CrossRef]

8. Hossain, M.U.; Poon, C.S.; Dong, Y.H.; Xuan, D. Evaluation of environmental impact distribution methods for supplementary cementitious materials. Renew. Sustain. Energy Rev. 2018, 82, 597-608. [CrossRef]

9. Amran, M.; Fediuk, R.; Murali, G.; Avudaiappan, S.; Ozbakkaloglu, T.; Vatin, N.; Karelina, M.; Klyuev, S.; Gholampour, A. Fly ash-based eco-efficient concretes: A comprehensive review of the short-term properties. Materials 2021, 14, 4264. [CrossRef]

10. Batayneh, M.; Marie, I.; Asi, I. Use of selected waste materials in concrete mixes. Waste Manag. 2007, 27, 1870-1876. [CrossRef] [PubMed]

11. Saha, S.; Rajasekaran, C. Mechanical properties of recycled aggregate concrete produced with Portland Pozzolana Cement. Adv. Concr. Constr. 2016, 4, 27-35.

12. Jin, R.Y.; Chen, Q. Investigation of concrete recycling in the U.S. construction industry. Procedia Eng. 2015, 118, 894-901. [CrossRef]

13. Khan, M.; Ali, M. Effectiveness of hair and wave polypropylene fibers for concrete roads. Constr. Build. Mater. 2018, 166, 581-591. [CrossRef]

14. Fraile-Garcia, E.; Ferreiro-Cabello, J.; López-Ochoa, L.M.; López-González, L.M. Study of the technical feasibility of increasing the amount of recycled concrete waste used in ready-mix concrete production. Materials 2017, 10, 817. [CrossRef] [PubMed]

15. Khan, M.; Rehman, A.; Ali, M. Efficiency of silica-fume content in plain and natural fiber reinforced concrete for concrete road. Constr. Build. Mater. 2020, 244, 118382. [CrossRef]

16. Etxeberria, M.; Vázquez, E.; Mari, A.; Barra, M. Influence of amount of recycled coarse aggregates and production process on properties of recycled aggregate concrete. Cem. Concr. Res. 2007, 37, 735-742. [CrossRef]

17. Meddah, M.S. Recycled aggregates in concrete production: Engineering properties and environmental impact. In Proceedings of the 1st International Conference on Engineering, Science and Technology (SICEST), Kota Palembang, Indonesia, 9-10 November 2016.

18. Czech Institute for Standards, Metrology and Testing. ČSN EN 12390-7, Testing Hardened Concrete—Part 7: Density of Hardened Concrete; Czech Office for Standards, Metrology and Testing: Prague, Czech Republic, 2020.

19. Czech Institute for Standards, Metrology and Testing. ČSN EN 12664, Thermal Performance of Building Materials and ProductsDetermination of Thermal Resistance by Means of Guarded Hot Plate and Heat Flow Meter Methods-Dry and Moist Products of Medium and Low Thermal Resistance; Czech Office for Standards, Metrology and Testing: Prague, Czech Republic, 2001.

20. ASTM International. ASTM D5334-14, Standard Test Method for Determination of Thermal Conductivity of Soil and Soft Rock by Thermal Needle Probe Procedure; ASTM International: West Conshohocken, PA, USA, 2014.

21. Czech Institute for Standards, Metrology and Testing. ČSN EN ISO 12572, Hygrothermal Performance of Building Materials and Products-Determination of Water Vapour Transmission Properties; Czech Office for Standards, Metrology and Testing: Prague, Czech Republic, 2001.

22. Vejmelková, E.; Pavlíková, M.; Jerman, M.; Černý, R. Free water intake as means of material characterization. J. Build. Phys. 2009, 33, 29-44. [CrossRef]

23. Czech Institute for Standards, Metrology and Testing. ČSN EN ISO 15148, Hygrothermal Performance of Building Materials and Products-Determination of Water Absorption Coefficient by Partial Immersion; Czech Office for Standards, Metrology and Testing: Prague, Czech Republic, 2004.

24. Roels, S.; Carmeliet, J.J.; Hens, H.; Adan, O.O.; Brocken, H.H.; Cerny, R.; Pavlik, Z.; Hall, C.; Kumaran, K.; Pel, L.L.; et al. Interlaboratory comparison of hygric properties of porous building materials. J. Therm. Envel. Build. Sci. 2004, 27, 307-325. [CrossRef]

25. Czech Institute for Standards, Metrology and Testing. ČSN EN 12390-3, Testing Hardened Concrete-Part 3: Compressive Strength of Test Specimens; Czech Office for Standards, Metrology and Testing: Prague, Czech Republic, 2020.

26. Maděra, J.; Kočí, J.; Kočí, V.; Kruis, J. Parallel modeling of hygrothermal performance of external wall made of highly perforated bricks. Adv. Eng. Softw. 2017, 113, 47-53. [CrossRef]

27. Jerman, M.; Černý, R. Effect of moisture content on heat and moisture transport and storage properties of thermal insulation materials. Energy Build. 2012, 53, 39-46. [CrossRef]

28. Kočí, V.; Maděra, J.; Jerman, M.; Žumár, J.; Koňáková, D.; Čáchová, M.; Vejmelková, E.; Reiterman, P.; Černý, R. Application of waste ceramic dust as a ready-to-use replacement of cement in lime-cement plasters: An environmental-friendly and energyefficient solution. Clean Technol. Environ. Policy 2016, 18, 1725-1733. [CrossRef]

29. Czech Institute for Standards, Metrology and Testing. ČSN EN ISO 15927-4, Hygrotermal Performance of Buildings-Calculation and Presentation of Climatic Data-Part 4: Hourly Data for Assessing the Annual Energy Use for Heating and Cooling; Czech Office for Standards, Metrology and Testing: Prague, Czech Republic, 2011. 
30. Czech Institute for Standards, Metrology and Testing. ČSN 730540-2, Thermal Protection of Buildings—Part 2: Requirements; Czech Office for Standards Metrology and Testing: Prague, Czech Republic, 2011.

31. Czech Institute for Standards, Metrology and Testing. ČSN EN ISO 19011, Guidelines for Auditing Management Systems; Czech Office for Standards, Metrology and Testing: Prague, Czech Republic, 2019.

32. Czech Institute for Standards, Metrology and Testing. ČSN EN ISO 14044, Environmental Management-Life Cycle AssessmentRequirements and Guidelines; Czech Office for Standards, Metrology and Testing: Prague, Czech Republic, 2019.

33. Kočí, J.; Fořt, J.; Kočí, V.; Hager, I. Assessment of environmental impact of coarse aggregates substitution by crushed pavements in concrete mixtures. In Proceedings of the MATEC Web of Conferences, 14 October 2020; Volume 322, p. 01036. Available online: https: / / doi.org/10.1051/matecconf/202032201036 (accessed on 25 November 2021).

34. Borghi, G.; Pantini, S.; Rigamonti, L. Life cycle assessment of non-hazardous Construction and Demolition Waste (CDW) management in Lombardy region (Italy). J. Clean. Prod. 2018, 184, 815-825. [CrossRef]

35. Rapa, M.; Gobbi, L.; Ruggieri, R. Environmental and economic sustainability of electric vehicles: Life cycle assessment and life cycle costing evaluation of electricity sources. Energies 2020, 13, 6292. [CrossRef]

36. Zilia, F.; Bacenetti, J.; Sugni, M.; Matarazzo, A.; Orsi, L. From waste to product: Circular economy applications from sea urchin. Sustainability 2021, 13, 5427. [CrossRef]

37. Pedreño-Rojas, M.; Fořt, J.; Cerny, R.; Rubio-De-Hita, P. Life cycle assessment of natural and recycled gypsum production in the Spanish context. J. Clean. Prod. 2020, 253, 120056. [CrossRef]

38. Kruszgeo, S.A. Dwudniaki Aggregates-Parameters. 2021. Available online: https://kruszgeo.com.pl/zek/dwudniaki.php (accessed on 13 October 2021).

39. Krawczyk, B.; Szydlo, A.; Mackiewicz, P.; Dobrucki, D. Suitability of aggregate recycled from concrete pavements for layers made of unbound and cement bound mixtures. Roads Bridges 2018, 17, 39-53.

40. Xuan, D.; Zhan, B.; Poon, C.S. Assessment of mechanical properties of concrete incorporating carbonated recycled concrete aggregates. Cem. Concr. Compos. 2016, 65, 67-74. [CrossRef]

41. Kurda, R.; de Brito, J.; Silvestre, J.D. A comparative study of the mechanical and life cycle assessment of high-content fly ash and recycled aggregates concrete. J. Build. Eng. 2020, 29, 101173. [CrossRef]

42. Fořt, J.; Černý, R. Transition to circular economy in the construction industry: Environmental aspects of waste brick recycling scenarios. Waste Manag. 2020, 118, 510-520. [CrossRef] 